Article

\title{
Shear Performance at Room and High Temperatures of Glass-Ceramic Sealants for Solid Oxide Electrolysis Cell Technology
}

\author{
Hassan Javed ${ }^{1, *(\mathbb{D})}$, Antonio Gianfranco Sabato ${ }^{1}$, Ivo Dlouhy ${ }^{2} \mathbb{D}$, Martina Halasova ${ }^{2}$, \\ Enrico Bernardo $^{3}{ }^{(\mathbb{D}}$, Milena Salvo ${ }^{1}{ }^{\circ}$, Kai Herbrig ${ }^{4}$, Christian Walter ${ }^{4}$ and Federico Smeacetto ${ }^{5}$ \\ 1 Department of Applied Science and Technology, Politecnico di Torino, Corso Duca Degli Abruzzi 24, \\ 10129 Turin, Italy; antonio.sabato@polito.it (A.G.S.); milena.salvo@polito.it (M.S.) \\ 2 Institute of Physics of Materials, Zizkova 22, 61662 Brno, Czech Republic; idlouhy@ipm.cz (I.D.); \\ halasova@ipm.cz (M.H.) \\ 3 Department of Industrial Engineering, Università degli Studi di Padova, via F. Marzolo 9, 35131 Padova, \\ Italy; enrico.bernardo@unipd.it \\ 4 Sunfire GmbH, Gasanstaltstraße 2, 01237 Dresden, Germany; Kai.Herbrig@sunfire.de (K.H.); \\ Christian.Walter@sunfire.de (C.W.) \\ 5 Department of Energy, Politecnico di Torino, Corso Duca Degli Abruzzi 24, 10129 Turin, Italy; \\ federico.smeacetto@polito.it \\ * Correspondence: hassan.javed@polito.it
}

Received: 21 December 2018; Accepted: 15 January 2019; Published: 18 January 2019 updates

\begin{abstract}
To provide a reliable integration of components within a solid oxide electrolysis cell stack, it is fundamental to evaluate the mechanical properties of the glass-ceramic sealing materials, as well as the stability of the metal-glass-ceramic interface. In this work, the mechanical behavior of two previously developed glass-ceramic sealants joined to Crofer22APU steel is investigated at room temperature, $650{ }^{\circ} \mathrm{C}$, and $850{ }^{\circ} \mathrm{C}$ under shear load. The mechanical properties of both the glass-ceramics showed temperature dependence. The shear strength of Crofer22APU/ glass-ceramic/Crofer22APU joints ranged from $14.1 \mathrm{MPa}\left(20^{\circ} \mathrm{C}\right)$ to $1.8 \mathrm{MPa}\left(850^{\circ} \mathrm{C}\right)$. The elastic modulus of both glass-ceramics also reduced with temperature. The volume fraction of the crystalline phases in the glass-ceramics was the key factor for controlling the mechanical properties and fracture, especially above the glass-transition temperature.
\end{abstract}

Keywords: glass-ceramic; shear strength; elastic modulus; SOFC; SOEC

\section{Introduction}

Solid oxide electrolysis cells (SOECs) are a promising technology to produce hydrogen through the electrolysis of water. Among the various components of an SOEC stack, the stability and performance of the glass-ceramic sealants are key factors to determine and control the overall efficiency of the system [1,2]. Because of the operational thermal regime of the whole stack, the joined components are subjected to the change of the acting stress, from almost compressive and/or tensile to almost shear. In laminate structures, this means that not only the SOEC materials, but also their interfaces often play a crucial role [3,4].

Due to cyclic temperature working conditions, there is a possibility of stress generation at the Crofer22APU/glass-ceramic interface and/or within the glass-ceramic joint. If the stresses increase to a critical level, either debonding at the Crofer22APU/glass-ceramic sealant interface or within the glass-ceramic can occur, thus causing gas leakage. Therefore, besides the thermal, chemical, thermomechanical and electrical stability of glass sealants, it is also important to analyze their 
response to mechanical loading under conditions corresponding to operational ones [5-10]. The high-temperature mechanical behavior of glass-ceramic sealants is crucial due to possible deterioration of these properties, especially if the working temperature is higher than the glass-transition temperature $\left(T_{g}\right)$ [11-13]. Recently, a few researchers have studied the mechanical properties of glass-ceramic sealants at room and high temperatures [14-21]. Selçuk et al. [18] employed three different testing methods to investigate the shear strength of glass-ceramic sealants, without specifying the glass-based composition: single lap offset (SLO) under compression, single lap (SL) under compression and asymmetrical 4-point bending test (A4PB). They found a significant variation in the apparent shear strength obtained by the different methods; specifically, the shear strength measured in the SLO configuration was relatively low (around $7 \mathrm{MPa}$ ), likely due to significant normal tensile stresses perpendicular to the joint. Stephens et al. [22] and Lin et al. [13] investigated the tensile and shear properties between the Crofer22APU interconnect and glass-ceramic sealants from room temperature to $800{ }^{\circ} \mathrm{C}$. Stephens et al. tested a barium-calcium-aluminosilicate-based glass-sealing material (G18); tensile and torsion tests were performed to characterize the interfacial shear strength between the G18 glass and the Crofer22APU. The mechanical strength of the joint decreased by almost $50 \%$ with an increase in temperature from $25{ }^{\circ} \mathrm{C}$ to $800{ }^{\circ} \mathrm{C}$ [22]. Lin et al. evaluated the joint strength of a $\mathrm{BaO}-\mathrm{B}_{2} \mathrm{O}_{3}-\mathrm{Al}_{2} \mathrm{O}_{3}-\mathrm{SiO}_{2}$ glass-ceramic joined to the Crofer22 $\mathrm{H}$ specimen, at room temperature and at $800{ }^{\circ} \mathrm{C}$ under shear and tensile loading. They evaluated the effect of ageing and pre-oxidation of the Crofer22 $\mathrm{H}$ and found that the tensile joint strength is lower if the fracture involves delamination at the interface between the steel substrate and $\mathrm{BaCrO}_{4}$ layer, formed by the reaction between $\mathrm{BaO}$ from the glass and $\mathrm{Cr}$ from the steel. Anyhow, by increasing the testing temperature, the shear strength reduced from $7 \mathrm{MPa}\left(25^{\circ} \mathrm{C}\right)$ to $4 \mathrm{MPa}\left(800{ }^{\circ} \mathrm{C}\right)[13]$.

In a paper by López et al. [23], the flexural strength of two glass-ceramic (one containing Ba and one containing $\mathrm{Sr}$ ) bars using a three-point bending setup after different ageing times was measured. Although the glass-ceramics were not interfaced with a metallic interconnect, interesting results were obtained in terms of the comparison between the mechanical properties of the two different glass-ceramic compositions. The authors discussed the mechanical behavior regarding different thermal ageing times of the glass-ceramics and their microstructural evolution. The glass-ceramics containing $\mathrm{SrO}$ exhibited higher flexural strength than the glass-ceramics with $\mathrm{BaO}$ [23].

In our work, the shear strength of the Crofer22APU/glass-ceramic/Crofer22APU joined samples was studied by using two SrO-containing glass-based systems, designed for a working temperature of $850^{\circ} \mathrm{C}$. The Crofer22APU/glass-ceramic/Crofer22APU samples were investigated under shear load at room temperature, $650{ }^{\circ} \mathrm{C}$ and $850{ }^{\circ} \mathrm{C}$. The elastic modulus of the glass-ceramics was also measured from room temperature to $650^{\circ} \mathrm{C}$ by vibration method.

\section{Materials and Methods}

Two previously developed glass-ceramic systems, further labeled as HJ3 and HJ4, are employed to investigate their mechanical behavior in contact with the Crofer22APU interconnect. The $T_{g}$ of the HJ3 and $\mathrm{HJ} 4$ glasses was $722^{\circ} \mathrm{C}$ and $736^{\circ} \mathrm{C}$, respectively, as measured by differential thermal analysis (DTA). Previously performed XRD analysis showed the presence of $\mathrm{Sr}_{2} \mathrm{Al}_{2} \mathrm{SiO}_{7}, \mathrm{Ca}_{0.75} \mathrm{Sr}_{0.2} \mathrm{Mg}_{1.05}\left(\mathrm{Si}_{2} \mathrm{O}_{6}\right)$ and $\mathrm{Ca}_{2} \mathrm{Mg}\left(\mathrm{Si}_{2} \mathrm{O}_{7}\right)$ phases in the $\mathrm{HJ} 3$ glass-ceramic, while the $\mathrm{HJ} 4$ glass-ceramic had $\mathrm{SrSiO}_{3}$ and $\mathrm{SiO}_{2}$ phases after joining [24].

The coefficients of thermal expansion (CTE) and the softening behavior of both the glass-ceramics were measured by dilatometer (Netzsch, DIL $402 \mathrm{PC} / 4$, Selb, Germany), at a heating rate of $5{ }^{\circ} \mathrm{C} / \mathrm{min}$. The dilatometer analyses were performed on the glass-ceramic pellets (diameter $1 \mathrm{~cm}$ ), prepared by pressing the glass powder in a steel mold, followed by a heat treatment in static air. Quantitative XRD analyses based on the Rietveld method were not feasible for the as-joined HJ3 and HJ4 glass-ceramics due to the complex crystalline phases and the corresponding XRD patterns. Consequently, in order to determine the relative quantities of the crystalline phases in the HJ3 and HJ4 as-joined glass-ceramics, an estimation could be made on the relative weight balance between the crystals 
in the glass-ceramics and the internal standard $(\mathrm{ZnO})$, introduced in a defined quantity (20 wt.\%). Therefore, the semi-quantitative analysis was performed by means of a Match software package (version 1.10, Crystal impact, Bonn, Germany), operating based on the reference intensity ratio method (RIR method) [25].

For mechanical characterization under quasistatic shear loading conditions, the Crofer22APU/glass-ceramic/Crofer22APU joined samples were prepared. Figure 1 illustrates the sample configuration (including dimensions) subsequently tested under shear load. Before joining, both plates of Crofer22APU were made plane parallel and polished to obtain the desired dimensions with a tolerance of $\pm 0.1 \mathrm{~mm}$. Each plate was cleaned by using acetone and subsequently the glass was deposited in the form of a slurry containing glass particles in ethanol (70:30 wt.\%). The joining of the HJ3 glass-ceramic with the Crofer22APU was carried out at $950{ }^{\circ} \mathrm{C}$ for $1 \mathrm{~h}$ at a heating rate of $5{ }^{\circ} \mathrm{C} / \mathrm{min}$, while for the $\mathrm{HJ} 4$ system the joining was processed at $950^{\circ} \mathrm{C}$ for $5 \mathrm{~h}$ at a heating rate of $2{ }^{\circ} \mathrm{C} / \mathrm{min}$. The glass-ceramics in the joining region had a thickness of $600 \mu \mathrm{m} \pm 50$. After joining, the samples were again gently polished for a few minutes to make sure that both steel plates were perfectly parallel to each other.

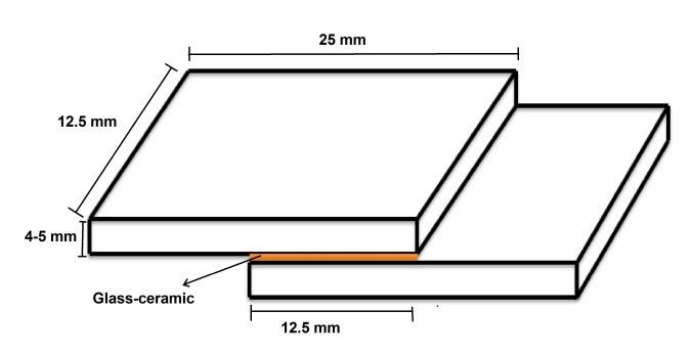

(a)

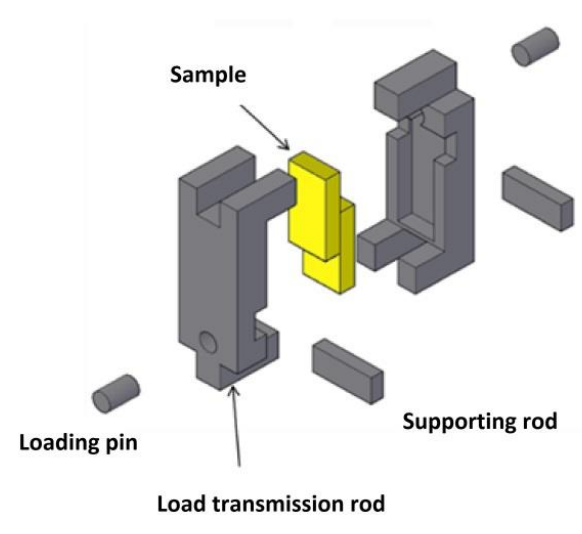

(b)

Figure 1. Illustration of Crofer22APU/glass-ceramic/Crofer22APU samples with glass-ceramic joint for shear testing (a) and setup for testing the sample under shear load (b).

Quasistatic shear testing was carried out at a constant machine cross-head rate of $50 \mu \mathrm{m} / \mathrm{min}$. The loading fixture developed for the experiments is also shown in Figure 1. The red arrows in Figure 1 indicate the direction of the applied load. Tests were conducted at three different testing temperatures, namely room temperature, $650^{\circ} \mathrm{C}$ and $850^{\circ} \mathrm{C}$. The displacement of the joined plates was quantified by using a high-temperature extensometer located outside the furnace. The Zwick/Roell-Messphysik Kappa $50 \mathrm{kN}$ test system with a Maytec inert gas high-temperature chamber was used for the experiments. The joint area of each sample was measured after the shear test by using a light microscope with CCD camera and image analysis. The shear stress was then calculated by dividing the applied load by the real joint area. All tests were conducted in an argon atmosphere. Before each test, the sample was heated to the desired temperature and kept at that temperature for $3 \mathrm{~h}$, to make the temperature homogenous throughout the heating zone of the chamber. The temperature was measured by a thermocouple attached directly to the sample. To obtain statistically representative data, at least three samples of both compositions were tested at each temperature. The post mortem analysis of broken samples was carried out by scanning electron microscope (SEM, Merlin ZEISS, Munich, Germany). For this purpose, cross sections of the Crofer22APU/glass-ceramic interfaces were metallographically polished up to $1 \mu \mathrm{m}$ by diamond paste and investigated by SEM after being coated with gold.

The elastic modulus of the pure glass-ceramics was measured by vibration method, at temperatures ranging from room temperature to $650^{\circ} \mathrm{C}$, during the heating and cooling cycles. For this 
purpose, thin rectangular samples of glass-ceramics with dimensions of $20 \mathrm{~mm} \times 2 \mathrm{~mm} \times 2 \mathrm{~mm}$ were prepared. The high-temperature impulse excitation technique, HT1600 system (IMCE, Belgium) was applied for these analyses. The elastic modulus was determined by measuring the resonant frequency of the sample at the given temperature and then calculated from the specimen dimensions and density.

\section{Results and Discussion}

The previously performed DTA on these glass systems showed a significant difference in crystallization behaviors. No crystallization peak was detected during the DTA analysis of the HJ4 glass, thus indicating that the crystallization was probably not sufficient to be detected. However, the DTA analysis of the HJ3 glass showed a crystallization peak due to the sufficient crystallization in that system [25].

The dilatometer curves of the HJ3 and HJ4 glass-ceramics are shown in Figure 2. The CTE of the as-joined HJ3 and HJ4 glass-ceramics were $10.2 \times 10^{-6} \mathrm{~K}^{-1}$ and $9.3 \times 10^{-6} \mathrm{~K}^{-1}$ respectively, in the temperature range of $200{ }^{\circ} \mathrm{C}-500{ }^{\circ} \mathrm{C}$. The dilatometer curve of the $\mathrm{HJ} 3$ as-joined glass-ceramic is quite linear, thus indicating that the $\mathrm{HJ} 3$ glass-ceramic did not become soft up to $1000^{\circ} \mathrm{C}$. Nevertheless, the dilatometer curve of the $\mathrm{HJ} 3$ glass-ceramic shows a slight change in the slope around $680{ }^{\circ} \mathrm{C}$, which is most likely due to the $T_{g}$ of the residual glassy phase. On the other hand, the dilatometer analysis of the HJ4 glass-ceramic shows that the HJ4 glass-ceramic became soft at around $800{ }^{\circ} \mathrm{C}$ with a $T_{g}$ around $700{ }^{\circ} \mathrm{C}$. These results further support the hypothesis that the as-joined HJ4 glass-ceramic has more residual glass than the as-joined HJ3 glass-ceramic.

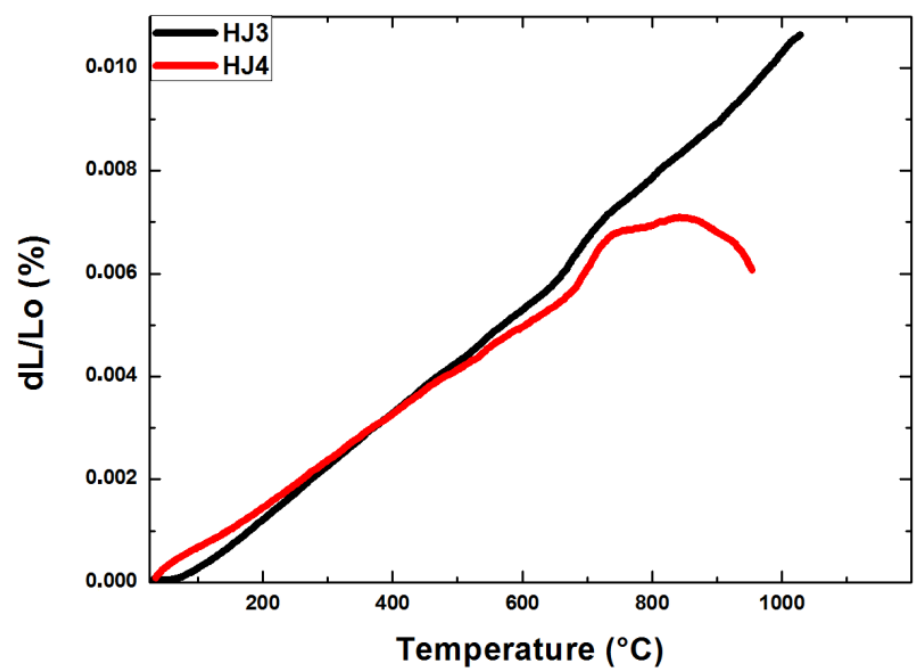

Figure 2. Dilatometer curves of as-joined HJ3 and HJ4 glass-ceramics. Measurements were carried out at a heating rate of $5^{\circ} \mathrm{C} / \mathrm{min}$.

Figure 3a shows the XRD analyses performed on the as-joined HJ3 and HJ4 glass-ceramics. Due to the complex crystalline phases (especially in HJ3), some peaks are unidentified, as shown in Figure $3 a, b$ shows the XRD patterns of both glass-ceramics after the inclusion of the standard $(\mathrm{ZnO})$. Closer inspection of the XRD reported in Figure $3 b$ shows the presence of a slightly more pronounced "amorphous halo" in the XRD pattern of the HJ4 glass-ceramic with respect to HJ3 system, thus undoubtedly indicating a relatively lower degree of crystallization in the HJ4 system. Even if the HJ4 system was processed for longer time in comparison with HJ3 ( $5 \mathrm{~h}$ vs. $1 \mathrm{~h}$ ), it maintained a significant amount of amorphous phase, as further supported by the dilatometer curves of the as-joined HJ3 and HJ4 glass-ceramics shown in Figure 2, thus highlighting a significant difference between the two compositions. These results agree with the results obtained from the DTA, HSM and dilatometer analyses of these glass-ceramics i.e., the HJ4 glass-ceramic has a relatively higher quantity of residual glass than the HJ3 as-joined glass-ceramic. 

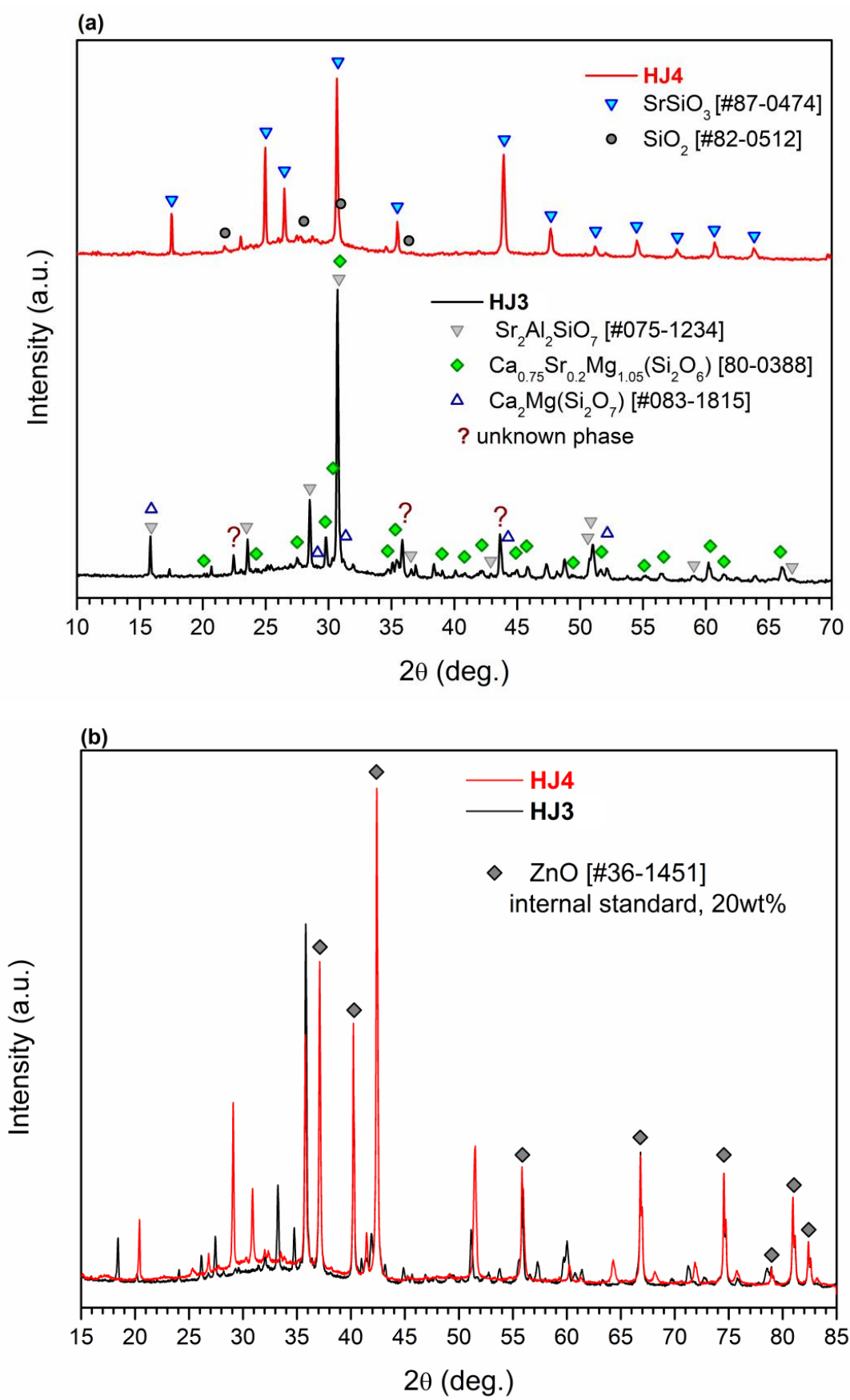

Figure 3. (a) Indexed XRD patterns of the HJ3 and HJ4 as-joined glass-ceramics (b) XRD pattern of as-joined glass-ceramics and $\mathrm{ZnO}$ standard.

Figure 4 shows the shear stress vs. load displacement curves for the HJ3 and HJ4 joint samples, tested at three different temperatures. For the sake of simplicity, only one curve has been shown for each temperature measurement. The traces reflect how the high temperatures significantly affect the deformation and fracture behavior of the joints made by the two different glass-ceramics. Please note that the slope of the linear part of the curves may be affected by an inexact determination of the joint area, as carried out by post mortem analysis of the fracture surfaces. When testing the Crofer22APU/glass-ceramic/Crofer22APU joints made of both glass-ceramics at room temperature and at $650{ }^{\circ} \mathrm{C}$ (lower than $T_{g}$ ), the fracture occurred in the linear mode once the applied stress reached maximum shear strength. This behavior reflects the almost elastic deformation and brittle response of the glass-ceramic joint. However, as expected, at $850{ }^{\circ} \mathrm{C}\left(\mathrm{T}>T_{g}\right)$, the joints showed enhanced 
displacement under the applied load and extensive non-linear behavior. This effect is due to the stress relaxation and the softening and viscous flow of the residual glassy phase above $T_{g}$, as observed by Zhao et al. [26]. Although both systems were crystallized after the heat treatments during the joining process, the residual glassy phase seemed to be the main factor controlling the mechanical behavior of the joint. As both glass systems were designed for a working temperature of $850{ }^{\circ} \mathrm{C}$, the stress relaxation phenomenon is favorable for reducing the thermal stresses that could be generated due to thermal mismatch at high temperature changes associated with the cell operation. Moreover, the residual glassy phase exhibiting viscous flow could also be beneficial for self-healing and consequently may enhance the long-term stability of the sealant. Chang et al. [12] observed the stress relaxation phenomenon for the as-joined and aged GC-9 glass-ceramic when tested in the temperature range of $650{ }^{\circ} \mathrm{C}-750^{\circ} \mathrm{C}$, and attributed it to the viscoelastic behavior of the residual glassy phase.
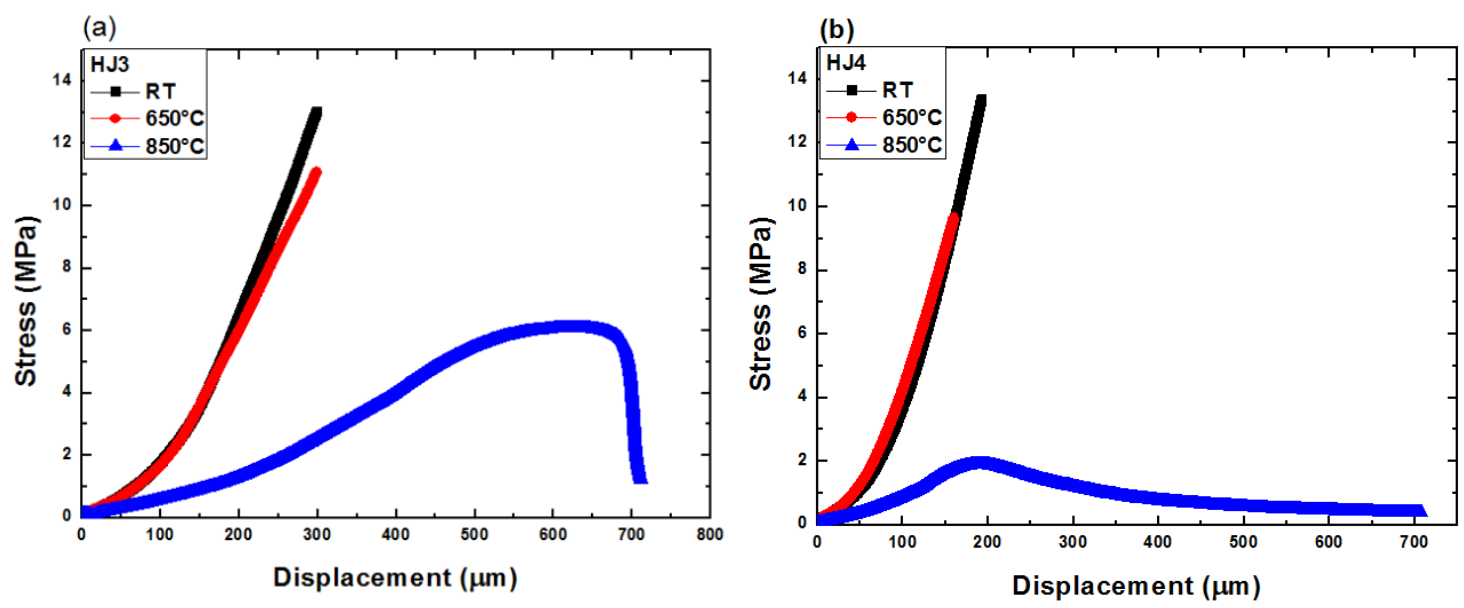

Figure 4. Shear stress vs. displacement curves for (a) HJ3 and (b) HJ4 joints, tested under shear loads at three different temperatures.

The shear strength values as determined and calculated from the stress displacement curves shown above (Figure 4) are given in Figure 5. Figure 5 shows the average shear strength obtained from three samples for each composition and at each test temperature. The shear strength of all the joints is seen to decrease with increasing testing temperatures. For the HJ3-based joints the strength reduced from 14.1 (at $25^{\circ} \mathrm{C}$ ) to $5.5 \mathrm{MPa}\left(850^{\circ} \mathrm{C}\right)$, while for the HJ4-based joints, the shear strength dropped from $13.9 \mathrm{MPa}\left(25^{\circ} \mathrm{C}\right)$ to $1.8 \mathrm{MPa}\left(850^{\circ} \mathrm{C}\right)$. The reduction observed in the strength with increasing temperature was according to expectations and is due to the softening of residual glassy phase at high temperature and its viscous flow (creep deformation). Because of the lower volume fraction of the crystalline phases within the $\mathrm{HJ} 4$, its shear strength reduced more drastically compared with the HJ3 glass-ceramic when increasing the testing temperature from $650{ }^{\circ} \mathrm{C}$ to $850{ }^{\circ} \mathrm{C}$. Osipova et al. [17] also investigated the shear strength of glass-ceramics at room temperature, $600{ }^{\circ} \mathrm{C}$ and $800{ }^{\circ} \mathrm{C}$ and found similar behavior of enhanced reduction in shear strength at $800{ }^{\circ} \mathrm{C}$, due to the softening of the remaining glassy phase.

It is worth highlighting that the HJ3-based joints fractured cohesively (fracture occurred within the glass-ceramic joint), while the HJ4-based joints fractured in an adhesive manner (fracture occurred at the Crofer22APU/glass-ceramic interface) for all the three testing temperatures. 


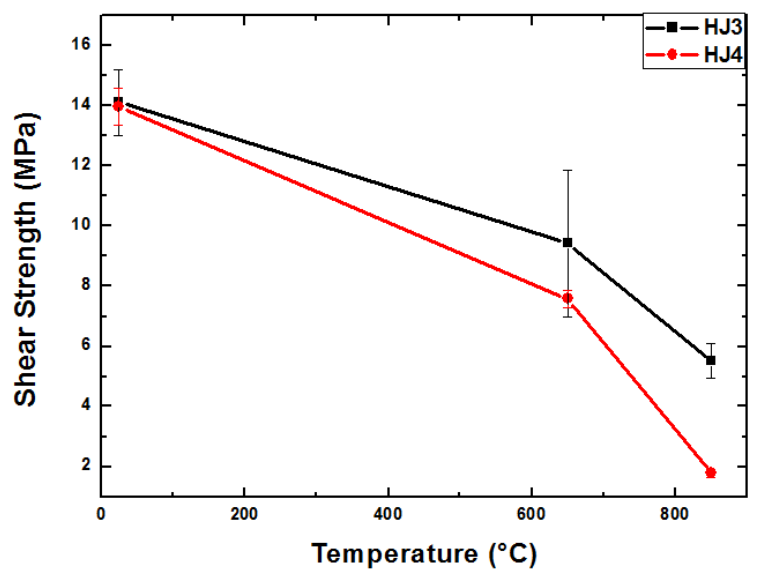

Figure 5. Comparison of shear strength of both glass systems as the function of test temperature.

Figure 6 shows the SEM images of the fractured surfaces of the joints based on both the glass systems. For the HJ4-based system, the adhesive fracture resulted in the detachment of the glass-ceramic from one of the joined Crofer22APU plates, therefore, the shown SEM images correspond to the Crofer22APU plate containing all the HJ4 glass-ceramic. The adhesive fracture occurred at one of the two Crofer22APU/HJ4 glass-ceramic interfaces, which resulted in the complete delamination of the HJ4 glass-ceramic at one interface. The corresponding SEM images (Figure 6a,b) of the Crofer22APU/HJ3/Crofer22APU samples tested at room temperature and $650{ }^{\circ} \mathrm{C}$ respectively, show that the glass-ceramics completely adhered throughout the joining area of both the Crofer22APU plates. However, for the $\mathrm{HJ} 3$ system-based joint tested at $850{ }^{\circ} \mathrm{C}$, the glass-ceramic was also partially detached from one of the Crofer22APU plates, as shown in Figure 6c. The fracture was probably initiated within the glass-ceramic bulk as in the case of low temperature testing, and then propagated to the interface.

Furthermore, overall thermal expansion coefficient (CTE) of a glass-ceramic, the CTE of individual crystal phases in that glass-ceramic system can play a key role in controlling the fracture behavior as they may create the stress concentration regimes, either within the glass-ceramics and/or at interface.

The HJ3 glass-ceramic has CTE of $10.2 \times 10^{-6} \mathrm{~K}^{-1}$ that is closely matching CTE of the Crofer22APU $\left(12 \times 10^{-6} \mathrm{~K}^{-1}\right)$ [27]; however, despite the presence of $\mathrm{Sr}_{2} \mathrm{Al}_{2} \mathrm{SiO}_{7}$ as main crystalline phase with a CTE of $1.1 \times 10^{-6} \mathrm{~K}^{-1}$ [28] that could generate localized stresses within the HJ3 glass-ceramic, the mechanical strength was found to be similar to $\mathrm{HJ} 4$ system (where $\mathrm{Sr}_{2} \mathrm{Al}_{2} \mathrm{SiO}_{7}$ is not present).

The HJ4 system has $\mathrm{SrSiO}_{3}$ as main crystalline phase having a CTE of $10.9 \times 10^{-6} \mathrm{~K}^{-1}$ [29], thus reducing localized stresses generation within the glass-ceramic. Anyway, the as-joined HJ4 glass-ceramic has a CTE of $9.3 \times 10^{-6} \mathrm{~K}^{-1}$ which is lower than that of Crofer22APU, therefore, it can lead to generate stresses at Crofer22APU/HJ4 glass-ceramic interface and make adhesive fracture more favorable under the externally applied load.

Furthermore, the presence of defects (pores or bubbles etc.) within the glass-ceramics can also lead to initiation of crack. The high degree of devitrification in the HJ3 glass-ceramic increases the possibility to generate residual micro porosity due to enhanced viscosity cause by crystallization. These micro pores could be another possible reason to initiate the crack within the HJ3 glass-ceramic. Hasanabadi et al. [9] also tested the Crofer22APU/glass-ceramic/Crofer22APU joints under torsion shear conditions and found that the presence of pores as major reason for crack initiation. On the other hand, even if the higher amount of the residual glassy phase in the HJ4 glass-ceramic minimizes the porosity due to its viscous behavior, the room temperature mechanical strength is not improved with respect to the HJ3 system, likely due to higher residual thermal stresses at the Crofer22APU/HJ4 glass-ceramic interface. 
The lower mechanical strength for $\mathrm{HJ} 4$ with respect to $\mathrm{HJ} 3$ at $650{ }^{\circ} \mathrm{C}$ could be attributed to the presence of cristobalite $\left(\mathrm{SiO}_{2}\right)$ phase in the HJ4 glass-ceramic [24], that has different polymorphs and cause volume expansion around $250{ }^{\circ} \mathrm{C}$, thus determining micro defects in the glass-ceramic at the interface with Crofer22APU.

The SEM images of fractured surfaces show the presence of micro pores in the HJ3 glass-ceramic (Figure 6a-c); however, the HJ4 glass-ceramic seems denser with slight residual porosity (Figure 6d-f).
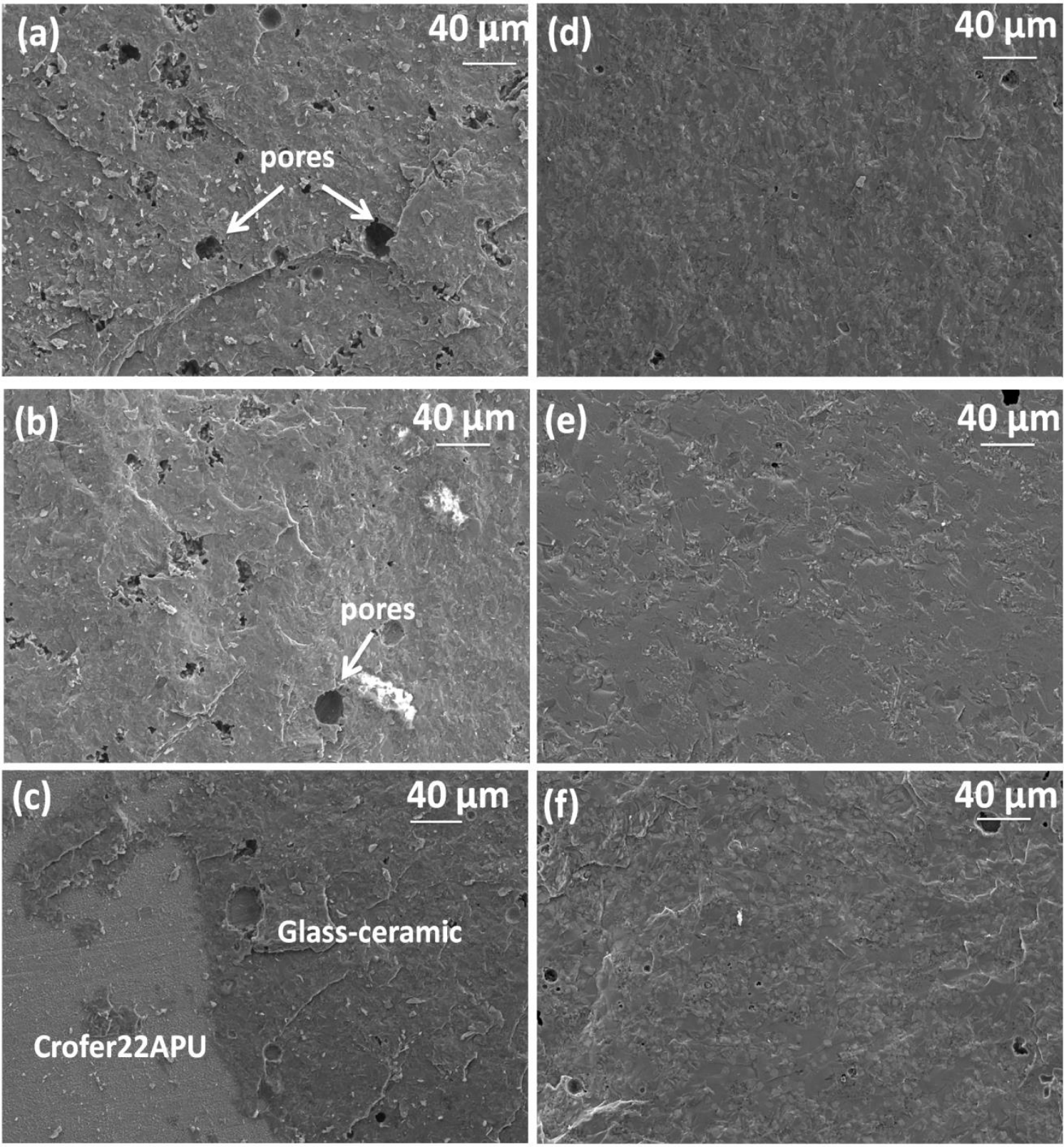

Figure 6. SEM images of top morphology of fracture surfaces of broken joint material; samples (a) HJ3 tested at RT, (b) HJ3 tested at $650{ }^{\circ} \mathrm{C},(\mathbf{c}) \mathrm{HJ} 3$ tested at $850{ }^{\circ} \mathrm{C},(\mathbf{d}) \mathrm{HJ} 4$ tested at RT, (e) HJ4 tested at 650 ${ }^{\circ} \mathrm{C}$, (f) $\mathrm{HJ} 4$ tested at $850{ }^{\circ} \mathrm{C}$.

Figure 7 shows the SEM images of the Crofer22APU/glass-ceramic interface for broken samples for both the glass systems tested at three different temperatures under shear load. For the HJ4 system, the images correspond to the Crofer22APU/HJ4 contained all the joined glass-ceramic well adhered to Crofer22APU surface after the fracture. The SEM images showed no cracks at glass-ceramics/Crofer22APU interfaces tested at room temperature as well as at high 
testing temperatures, thus demonstrating a good thermomechanical compatibility. A uniform microstructure of both the glass-ceramics was observed. For a particular glass system, the Crofer22APU/glass-ceramic interfaces showed a similar morphology after being tested at three different temperatures. Further details about the microstructure of both the glass-ceramics can be found elsewhere [24].
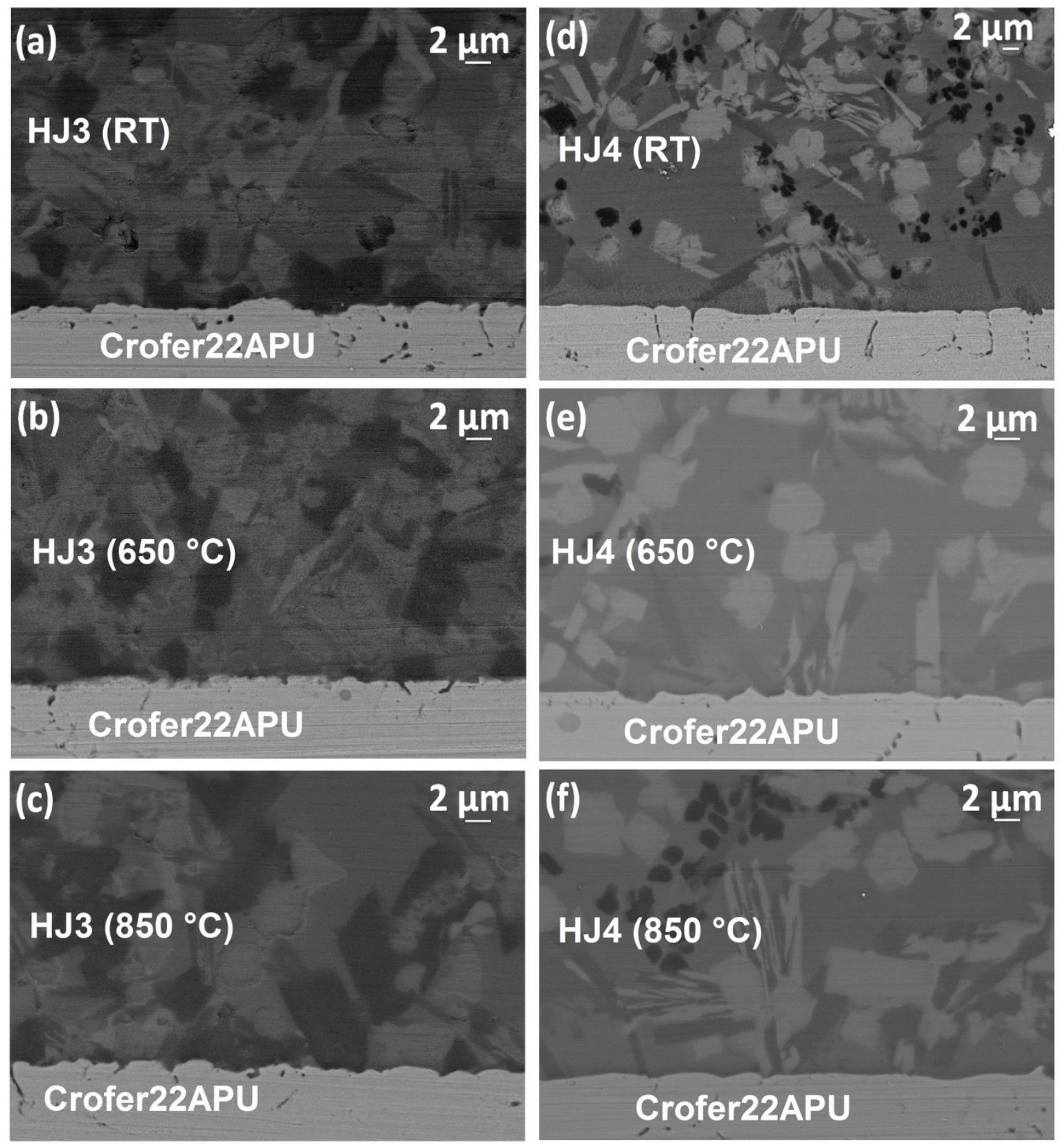

Figure 7. SEM images of interface of Crofer22APU with (a) HJ3 tested at RT, (b) HJ3 tested at $650{ }^{\circ} \mathrm{C}$, (c) $\mathrm{HJ} 3$ tested at $850{ }^{\circ} \mathrm{C}$, (d) $\mathrm{HJ} 4$ tested at RT, (e) $\mathrm{HJ} 4$ tested at $650{ }^{\circ} \mathrm{C},(\mathbf{f}) \mathrm{HJ} 4$ tested at $850{ }^{\circ} \mathrm{C}$. Details about the microstructure of both the glass-ceramics can be found elsewhere [24].

The elastic moduli of the as-joined glass-ceramics for both the glass systems are shown in Figure 8. Measurements were performed from room temperature to $650^{\circ} \mathrm{C}$ and elastic modulus was measured both during the heating and cooling. Above $650{ }^{\circ} \mathrm{C}$, the obtained resonance frequencies were not sufficient to measure the reliable values due to the possible softening of the glass-ceramics. The direct comparison shows that the HJ3 glass-ceramic (Figure 8a) has higher values of elastic modulus 
as compared with the HJ4 system (Figure 8b). The higher volume fraction of crystals in the HJ3 glass-ceramic made this system stiffer than the HJ4 glass-ceramic. Similar behavior was observed by Milhans et al. [30], where reduced modulus was observed to increase with increasing volume content of the crystalline phases in the glass-ceramics, as measured by nanoindentation. Zhao et al. [31] also compared the elastic modulus of different glass-ceramic systems having different amounts of the residual glassy phases. The glass-ceramic with less quantity of residual glassy phase showed higher elastic modulus. For the HJ3 glass-ceramic, the elastic modulus reduced from $100 \mathrm{GPa}$ (at room temperature) to $92 \mathrm{GPa}\left(650^{\circ} \mathrm{C}\right)$, whereas for the HJ4 glass-ceramic it decreased from $80 \mathrm{GPa}$ (room temperature) to $75 \mathrm{GPa}\left(650^{\circ} \mathrm{C}\right)$. The elastic modulus curve for the $\mathrm{HJ} 4$ glass-ceramic (Figure 8 ) also shows discontinuities around $230^{\circ} \mathrm{C}$ during heating cycle and around $230^{\circ} \mathrm{C}-270{ }^{\circ} \mathrm{C}$ during cooling. This is due to the presence of cristobalite $\left(\mathrm{SiO}_{2}\right)$ phase in the HJ4 glass-ceramic [24,32]. Nevertheless, the obtained elastic moduli for both the systems (HJ3 and HJ4) are comparable or slightly higher than the elastic modulus of the glass-ceramics available in the literature (50-80 GPa) $[8,22,30,31,33,34]$.

(a)

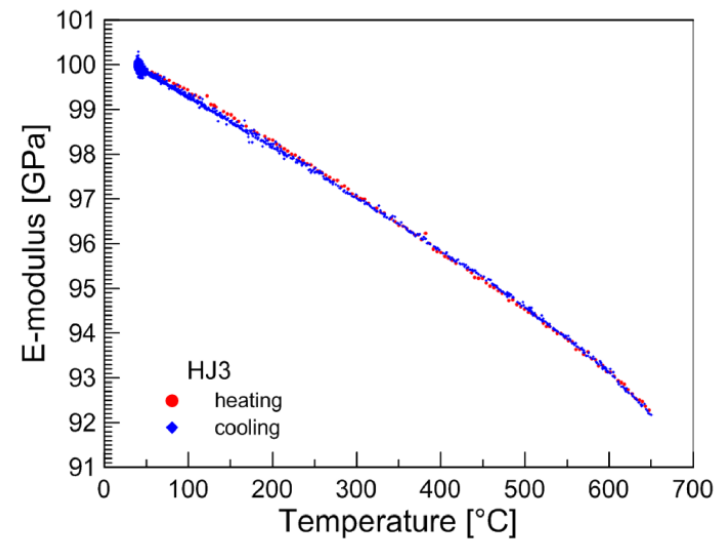

(b)

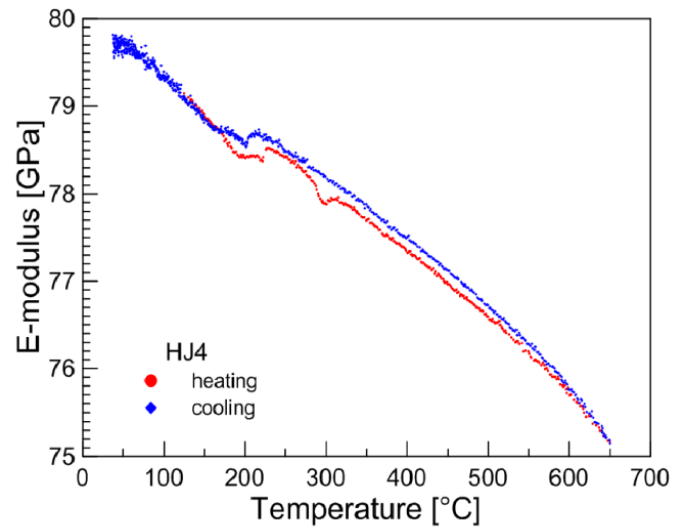

Figure 8. Elastic modulus of as-joined (a) HJ3 and (b) HJ4 glass-ceramics, measurement was done from room temperature to $650^{\circ} \mathrm{C}$.

\section{Conclusions}

Mechanical testing in shear conditions performed at room temperature, $650{ }^{\circ} \mathrm{C}$ and $850{ }^{\circ} \mathrm{C}$ enabled to quantify the temperature dependence of the investigated shear parameters. The mechanical strength of both glass-ceramic-joined samples tested at $650{ }^{\circ} \mathrm{C}$ was retained up to $60-70 \%$ of the RT values, while a substantial decrease was observed at $850{ }^{\circ} \mathrm{C}\left(\mathrm{T}>\mathrm{T}_{g}\right)$.

Similarly, as expected the elastic modulus of both the glass-ceramics also showed nearly linear reduction with temperature. The volume fraction of the crystalline phases has been found to be an important factor controlling the mechanical properties at high temperatures. The higher amount of 
residual glassy phase in the glass-ceramic reduces the high-temperature mechanical properties of the sealant but promotes the stress relaxation possibilities due to softening, which is beneficial to release the thermal stresses at high temperature.

This study provides insights for design and development of glass-ceramic sealants for SOEC working at $850^{\circ} \mathrm{C}$.

Author Contributions: H.J. prepared the samples for the mechanical testing and wrote the manuscript. A.G.S. conducted the SEM post mortem analysis. I.D. and M.H. performed the high-temperature mechanical testing. E.B. performed the XRD analysis and quantification of crystalline phases in the glass-ceramics. M.S. and K.H. helped in preparing the manuscript. C.W. and F.S. supervised the whole work and helped in interpretation of data. All the authors discussed the results and gave valuable inputs while preparing the final manuscript.

Funding: The project leading to this research has received funding from "The Fuel Cells and Hydrogen 2 Joint Undertaking under grant agreement No 700300 (GrInHy-Green Industrial Hydrogen via reversible high-temperature electrolysis)" and "European Union's Horizon 2020 research and innovation programme and Hydrogen Europe and N.ERGHY; The European Union's Horizon 2020 research and innovation programme under the Marie Skłodowska-Curie grant agreement No 642557 (CoACH-ETN)".

Conflicts of Interest: The authors declare no conflict of interest.

\section{References}

1. Kazempoor, P.; Braun, R.J. Hydrogen and synthetic fuel production using high temperature solid oxide electrolysis cells (soecs). Int. J. Hydrog. Energy 2015, 40, 3599-3612. [CrossRef]

2. Xiaoyu, Z.; James, E.O.B.; Robert, C.O.B.; Joseph, J.H.; Greg, T.; Gregory, K.H. Improved durability of soec stacks for high temperature electrolysis. Int. J. Hydrogen Energy 2013, 38, 20-28.

3. Boccaccini, D.N.; Sevecek, O.; Frandsen, H.L.; Dlouhy, I.; Molin, S.; Charlas, B.; Hjelm, J.; Cannio, M.; Hendriksen, P.V. Determination of the bonding strength in solid oxide fuel cells' interfaces by schwickerath crack initiation test. J. Eur. Ceram. Soc. 2017, 37, 3565-3578. [CrossRef]

4. Boccaccini, D.N.; Sevecek, O.; Frandsen, H.L.; Dlouhy, I.; Molin, S.; Cannio, M.; Hjelm, J.; Hendriksen, P.V. Investigation of the bonding strength and bonding mechanisms of sofcs interconnector-electrode interfaces. Mater. Lett. 2016, 162, 250-253. [CrossRef]

5. Cela Greven, B.; Gross-Barsnick, S.M.; Federmann, D.; Conradt, R. Strength evaluation of multilayer glass-ceramic sealants. Fuel Cells 2013, 13, 565-571. [CrossRef]

6. Hamid, A.; Parvin, A.; Dino, B.; Karsten, A. Fracture toughness of glass sealants for solid oxide fuel cell application. Mater. Lett. 2014, 115, 75-78.

7. Cela Greven, B.; Gross-Barsnick, S.; Koppitz, T.; Conradt, R.; Smeacetto, F.; Ventrella, A.; Ferraris, M. Torsional shear strength of novel glass-ceramic composite sealants for solid oxide fuel cell stacks. Int. J. Appl. Ceram. Technol. 2018, 15, 286-295. [CrossRef]

8. Bodhayan, D.; Mark, E.W.; Gene, B.A.; Scott, L.S. Mechanical and thermal characterization of a ceramic/glass composite seal for solid oxide fuel cells. J. Power Sources 2014, 245, 958-966.

9. Hasanabadi, M.F.; Faghihi-Sani, M.A.; Kokabi, A.H.; Malzbender, J. The analysis of torsional shear strength test of sealants for solid oxide fuel cells. Ceram. Int. 2017, 43, 12546-12550. [CrossRef]

10. Hamada, E.; Hassan, J.; Antonio, G.S.; Federico, S.; Enrico, B. Novel glass-ceramic sofc sealants from glass powders and a reactive silicone binder. J. Eur. Ceram. Soc. 2018, 38, 4245-4251.

11. Malzbender, J.; Mönch, J.; Steinbrech, R.W.; Koppitz, T.; Gross, S.M.; Remmel, J. Symmetric shear test of glass-ceramic sealants at sofc operation temperature. J. Mater. Sci. 2007, 42, 6297-6301. [CrossRef]

12. Chang, H.-T.; Lin, C.-K.; Liu, C.-K. Effects of crystallization on the high-temperature mechanical properties of a glass sealant for solid oxide fuel cell. J. Power Sources 2010, 195, 3159-3165. [CrossRef]

13. Liu, C.-K.; Liu, Y.-A.; Wu, S.-H.; Liu, C.-K.; Lee, R.-Y. Joint strength of a solid oxide fuel cell glass-ceramic sealant with metallic interconnect in a reducing environment. J. Power Sources 2015, 280, 272-288.

14. Hasanabadi, M.F.; Faghihi-Sani, M.A.; Kokabi, A.H.; Groß-Barsnick, S.M.; Malzbender, J. Room- and high-temperature flexural strength of a stable solid oxide fuel/electrolysis cell sealing material. Ceram. Int. 2019, 45, 733-739. [CrossRef]

15. Jeffrey, W.F. Sealants for solid oxide fuel cells. J. Power Sources 2005, 147, 46-57. 
16. Hasanabadi, M.F.; Kokabi, A.H.; Faghihi-Sani, M.A.; Groß-Barsnick, S.M.; Malzbender, J. Room- and high-temperature torsional shear strength of solid oxide fuel/electrolysis cell sealing material. Ceram. Int. 2018, 45, 2219-2225. [CrossRef]

17. Osipova, T.; Wei, J.; Pećanac, G.; Malzbender, J. Room and elevated temperature shear strength of sealants for solid oxide fuel cells. Ceram. Int. 2016, 42, 12932-12936. [CrossRef]

18. Selçuk, A.; Atkinson, A. Measurement of mechanical strength of glass-to-metal joints. Fuel Cells 2015, 15, 595-603. [CrossRef]

19. Jacqueline, M.; Mohammed, K.; Xin, S.; Mehran, T.; Marwan, A.-H.; Garmestani, H. Creep properties of solid oxide fuel cell glass-ceramic seal g18. J. Power Sources 2010, 195, 3631-3635.

20. Selahattin, C. Influential parameters and performance of a glass-ceramic sealant for solid oxide fuel cells. Ceram. Int. 2015, 41, 2744-2751.

21. Smeacetto, F.; Miranda, A.D.; Ventrella, A.; Salvo, M.; Ferraris, M. Shear strength tests of glass ceramic sealant for solid oxide fuel cells applications. Adv. Appl. Ceram. 2010, 114, S70-S75. [CrossRef]

22. Stephens, E.V.; Vetrano, J.S.; Koeppel, B.J.; Chou, Y.; Sun, X.; Khaleel, M.A. Experimental characterization of glass-ceramic seal properties and their constitutive implementation in solid oxide fuel cell stack models. J. Power Sources 2009, 193, 625-631. [CrossRef]

23. Rodríguez-López, S.; Wei, J.; Laurenti, K.C.; Mathias, I.; Justo, V.M.; Serbena, F.C.; Baudín, C.; Malzbender, J.; Pascual, M.J. Mechanical properties of solid oxide fuel cell glass-ceramic sealants in the system bao/sro-mgo-b2o3-sio2. J. Eur. Ceram. Soc. 2017, 37, 3579-3594. [CrossRef]

24. Javed, H.; Sabato, A.G.; Herbrig, K.; Ferrero, D.; Walter, C.; Salvo, M.; Smeacetto, F. Design and characterization of novel glass-ceramic sealants for solid oxide electrolysis cell (soec) applications. Int. J. Appl. Ceram. Technol. 2018, 15, 999-1010. [CrossRef]

25. Hillier, S. Accurate quantitative analysis of clay and other minerals in sandstones by xrd: Comparison of a rietveld and a reference intensity ratio (rir) method and the importance of sample preparation. Clay Miner. 2000, 35, 291-302. [CrossRef]

26. Yilin, Z.; Jürgen, M. Elevated temperature effects on the mechanical properties of solid oxide fuel cell sealing materials. J. Power Sources 2013, 239, 500-504.

27. Ghosh, S.; Sharma, A.D.; Kundu, P.; Basuz, R.N. Glass-ceramic sealants for planar it-sofc: A bilayered approach for joining electrolyte and metallic interconnect. J. Electrochem. Soc. 2008, 155, B473-B478. [CrossRef]

28. Manu, K.M.; Ananthakumar, S.; Sebastian, M.T. Electrical and thermal properties of low permittivity sr2al2sio7 ceramic filled hdpe composites. Ceram. Int. 2013, 39, 4945-4951. [CrossRef]

29. Thieme, C.; Rüssel, C. Thermal expansion behavior of srsio3 and sr2sio4 determined by high-temperature x-ray diffraction and dilatometry. J. Mater. Sci. 2015, 50, 5533-5539. [CrossRef]

30. Milhans, J.; Ahzi, S.; Garmestani, H.; Khaleel, M.A.; Sun, X.; Koeppel, B.J. Modeling of the effective elastic and thermal properties of glass-ceramic solid oxide fuel cell seal materials. Mater. Des. 2009, 30, 1667-1673. [CrossRef]

31. Yilin, Z.; Jürgen, M.; Sonja, M.G. The effect of room temperature and high temperature exposure on the elastic modulus, hardness and fracture toughness of glass ceramic sealants for solid oxide fuel cells. J. Eur. Ceram. Soc. 2011, 31, 541-548.

32. Beals, M.D.; Zerfoss, S. Volume change attending low-to-high inversion of cristobalite. J. Am. Ceram. Soc. 1944, 27, 285-292. [CrossRef]

33. Liu, W.; Su, X.; Khaleel, M.A. Predicting young's modulus of glass/ceramic sealant for solid oxide fuel cell considering the combined effects of aging, micro-voids and self-healing. J. Power Sources 2008, 185, 1193-1200. [CrossRef]

34. Milhans, J.; Li, D.S.; Khaleel, M.; Sun, X.; Marwan, S.A.-H.; Adrian, H.; Garmestani, H. Mechanical properties of solid oxide fuel cell glass-ceramic seal at high temperatures. J. Power Sources 2011, 196, 5599-5603. [CrossRef]

(C) 2019 by the authors. Licensee MDPI, Basel, Switzerland. This article is an open access article distributed under the terms and conditions of the Creative Commons Attribution (CC BY) license (http:/ / creativecommons.org/licenses/by/4.0/). 